\title{
7-2015
}

\section{Tools for Outreach Presentations}

\author{
Ronald I. Greenberg \\ Loyola University Chicago, Rgreen@luc.edu \\ Dale Reed \\ University of Illinois at Chicago, reed@uic.edu
}

Follow this and additional works at: https://ecommons.luc.edu/cs_facpubs

Part of the Computer Sciences Commons, Science and Mathematics Education Commons, and the Secondary Education Commons

Author Manuscript

This is a pre-publication author manuscript of the final, published article.

\section{Recommended Citation}

Ronald I. Greenberg and Dale Reed. Tools for outreach presentations. In Proceedings of the 20th Annual SIGCSE Conference on Innovation and Technology in Computer Science Education (ITiCSE), page 331. ACM SIGCSE, July 2015.

This Article is brought to you for free and open access by the Faculty Publications and Other Works by Department at Loyola eCommons. It has been accepted for inclusion in Computer Science: Faculty Publications and Other Works by an authorized administrator of Loyola eCommons. For more information, please contact ecommons@luc.edu.

\section{(c) (i) $\ominus$}

This work is licensed under a Creative Commons Attribution-Noncommercial-No Derivative Works 3.0 License. 


\section{Tools for Outreach Presentations}

\author{
Ronald I. Greenberg \\ Loyola University Dept. of Computer Science \\ 820 N. Michigan Ave. \\ Chicago, IL 60611-2147 \\ rig@cs.luc.edu
}

\author{
Dale Reed \\ U. of Illinois at Chicago Dept. of Computer Sci. \\ 851 S. Morgan St. (MC 152) \\ Chicago, IL 60607-7053 \\ reed@uic.edu
}

\begin{abstract}
We present resources we have constructed and culled from the internet that can be used in computing outreach visits in $\mathrm{K}-12$ classrooms, especially high schools. We have used such tools at about 100 schools, reaching several thousand students, and achieving positive attitudinal responses in surveys of several hundred of these students.
\end{abstract}

\section{Categories and Subject Descriptors}

K.3.0 [Computers and Education]: General

\section{Keywords}

Computing outreach; computer science outreach

\section{INTRODUCTION}

Inspired by Carnegie Mellon University's Women@SCS Roadshow, we embarked on an extensive effort (assisted by university students and staff and National Science Foundation funding) to visit high school classrooms in the Chicago area; we reached several thousand students and surveyed over 400 . $74 \%$ to $88 \%$ of survey respondents liked ("good" or "very good") each of our presentation elements. Furthermore, $63 \%$ to $70 \%$ agreed or strongly agreed that they gained a greater recognition of the diversity of people working in computing-related fields, learned more about the kinds of computing-related work people do, and learned more about the availability of computing-related career opportunities; additionally, over half the respondents indicated increased interest in pursuing a college major in computer science. Our efforts also enhanced our network of high school contacts, contributing to the Chicago CSTA group being one of the largest in the country, and helping to build the community that has led to professional development for the Exploring Computer Science (ECS) curriculum being provided to 140 Chicago Public Schools high school teachers.

We provide here an overview of effective elements from which our presentations sampled. Most can be accessed at

Permission to make digital or hard copies of part or all of this work for personal or classroom use is granted without fee provided that copies are not made or distributed for profit or commercial advantage, and that copies bear this notice and the full citation on the first page. Copyrights for third-party components of this work must be honored. For all other uses, contact the owner/author(s). Copyright is held by the author/owner(s).

ITiCSE'15, July 6-8, 2015, Vilnius, Lithuania.

ACM 978-1-4503-3440-2/15/07.

http://dx.doi.org/10.1145/2729094.2754866. http://illinoiscomputes.org/hspresent; they are generally suitable for continued use or provide good examples on which to base an update or adaptation to a different locale.

\section{PRESENTATION ELEMENTS}

The elements used in our presentations can be broadly characterized as responding to four questions as follows:

Who does computer science?

The main approach to increase appreciation of the diversity of computer scientists was to show many pictures of computer scientists (more than in other outreach presentations), along with a few of other people, and to ask students to identify the people who are not computer scientists.

What is computer science about?

Principal items utilized in this area included excerpts from the CMU Roadshow, a slide show by Jeanette Wing on uses of computational thinking in various subject areas, robotics videos, visualization sites such as Name Voyager and Photosynth, and technologies to assist persons with disabilities, such as Dasher and "tongue vision"; these all helped students see some of the kinds of things they could work on as computer scientists. We also created handy online tools to perform "magic" tricks based on computer science concepts.

Are there jobs for computer scientists?

Data and news articles were presented to show that computing is dominant among occupations providing high pay, good working conditions, and strong projected growth in number of jobs. Also often cited was the gap between job openings and university degree production in computing fields.

How can I prepare to be active in computer science? Presenters generally incorporated pointers about preparing for computing studies and careers in the overall presentation as well as during the question/answer period at the end. Reassurance also was provided for students who may have limited pre-college options to study computing or misconceptions about their own match for the subject. For example, students were told that computing can be studied at the college level without substantial prior experience, but that it is always good to seek out computing-related instruction in high school that goes beyond just using applications such as word processors and spreadsheets. Students were also encouraged to learn about application areas of interest, since computing is so interdisciplinary, and they were reassured that whether they love mathematics or not, there are appropriate areas of computer science. Sometimes, the presenters also pointed out contests for high school students. 